\title{
Molecular identification of Salmonella Typhimurium from village chickens based on invA and spvC genes
}

\author{
Mwanaisha Mkangara ${ }^{1,2}$, Ernest R. Mbega ${ }^{1}$ and Musa Chacha ${ }^{1}$ \\ 1. Department of Sustainable Agriculture and Biodiversity and Ecosystems Management, Nelson Mandela African \\ Institution of Science and Technology, Arusha, Tanzania; 2. Department of Science and Laboratory Technology, \\ Dar es Salaam Institute of Technology, Dar es Salaam, Tanzania. \\ Corresponding author: Mwanaisha Mkangara, e-mail: mkangaram@yahoo.com \\ Co-authors: ERM: ernest.mbega@nm-aist.ac.tz, MC: musa.chacha@nm-aist.ac.tz \\ Received: 17-09-2019, Accepted: 11-03-2020, Published online: 23-04-2020
}

doi: www.doi.org/10.14202/vetworld.2020.764-767 How to cite this article: Mkangara M, Mbega ER, Chacha M (2020) Molecular identification of Salmonella Typhimurium from village chickens based on invA and spvC genes, Veterinary World, 13(4): 764-767.

\begin{abstract}
Aim: This study aimed to identify Salmonella enterica serovars by polymerase chain reaction (PCR) based on virulence genes invasion A (invA) and Salmonella plasmid virulence C ( $p p v C)$.

Materials and Methods: DNA extraction of eight bacteria isolates was done using the PowerSoil ${ }^{\circledR}$ DNA Isolation Kit. The amplification of $i n v A$ and $s p v C$ genes was done using conventional PCR. The positive PCR products were purified using the GeneJET Purification Kit and then sequenced using ABI 3730 XL automated genetic analyzer. The sequences obtained were compared for similarities with other Salmonella serovars deposited on the NCBI GenBank using BLASTN.

Results: Four out of eight samples were amplified by primers FS139/RS141 that target invA gene with products of about $284 \mathrm{bp}$, and three out of four of the same invA positive samples were also amplified by primers FSPV-1/RSPV-2 targeting $s p v C$ with a product of about $571 \mathrm{bp}$. One sample was not amplified by primers FSPV-1/RSPV-2 as it lacked virulence plasmid. Analysis of sequences indicated $100 \%$ homology with closely related serovars of $S$. enterica subspecies enterica serovar Typhimurium.
\end{abstract}

Conclusion: Salmonella Typhimurium that contained $i n v A$ and $s p v C$ genes are pathogenic and virulent strains.

Keywords: invasive gene A, polymerase chain reaction, Salmonella plasmid virulence gene, Salmonella Typhimurium, sequencing.

\section{Introduction}

Salmonella enterica serovar Typhimurium (Salmonella Typhimurium) is a motile Gram-negative bacterium in family Enterobacteriaceae [1]. The bacterium is one among serovars with broad host range responsible for gastroenteritis in chickens but rarely induce systemic infection [2]. In young chickens, S. Typhimurium results in severe inflammation and intestinal pathology [3]. However, in some cases, the pathogen does not cause noticeable clinical symptoms in older chickens $[4,5]$. Under these circumstances, the older chickens become carriers of $S$. Typhimurium, which colonizes the gut with persistent shedding of bacteria that contaminate different environments [6-9]. The carrier chickens with salmonellosis are among sources of contaminated chicken products in the abattoirs with the significance of forming biofilm layers in equipment involved in the value chain [10]. The biofilm contributes to the persistence of Salmonella in different biotic

Copyright: Mkangara, et al. Open Access. This article is distributed under the terms of the Creative Commons Attribution 4.0 International License (http://creativecommons.org/licenses/ by/4.0/), which permits unrestricted use, distribution, and reproduction in any medium, provided you give appropriate credit to the original author(s) and the source, provide a link to the Creative Commons license, and indicate if changes were made. The Creative Commons Public Domain Dedication waiver (http:// creativecommons.org/publicdomain/zero/1.0/) applies to the data made available in this article, unless otherwise stated. and abiotic surfaces and protects the bacterium against antibiotics and disinfectants [11]. On the other side, salmonellosis is zoonotic; therefore, chicken products contaminated with $S$. Typhimurium increase number of gastroenteritis infections to humans who are the most affected than any other group worldwide [12].

There are different methods of identifying pathogenic microbes from clinical samples [13]. The best choices consider techniques which are cost-effective, accurate, rapid, and easier to use to improve diagnostic testing with the outcome of right treatments in a shorter time [14]. The conventional microbiological methods, including culture using selective medium, microscopy, Gram staining, and biochemical tests are labor-intensive, time-consuming with low specificity $[15,16]$. In contrary to these methods, the polymerase chain reaction (PCR) is the confident and rapid technique of detecting clinical samples with higher specificity and sensitivity $[17,18]$. Therefore, the PCR methods qualify for the identification of any number of pathogens using specific primers that amplify the minimal part of the genome. The invasion A $(i n v A)$ is an invasion-related gene located in Salmonella pathogenicity island-1 [19]. The gene is responsible for the invasion of epithelial cells and the induction of macrophage apoptosis [20]. The inv $A$ gene is a conserved virulence gene in nearly all Salmonella species; therefore, the right candidate for 
the detection of Salmonella using different PCR methods [20]. The study also selected the Salmonella plasmid virulence $\mathrm{C}(s p v C)$ gene, which is of virulence plasmid for detecting strains associated with non-typhoid bacteremia [21]. Salmonella has plasmids with a highly conserved locus known as $s p v$ operon. The operon consists of five genes $s p v R A B C D$ essential for Salmonella virulence [22]. However, not all Salmonella serovars consist of spv genes [23].

Therefore, the present study used conventional PCR for the detection of virulence genes invA and $s p v C$ in Salmonella spp. isolated from fecal samples of chickens.

\section{Materials and Methods}

\section{Ethical approval}

This study got approval from Kibong'oto Infectious Diseases Hospital, Nelson Mandela African Institution of Science and Technology (NM AIST) and Centre for Educational Development in Health, Health Research Committee with approval number KNCHREC006.

\section{Bacterial isolates}

Eight bacterial isolates used in this study were among 54 bacteria isolates obtained from fecal samples of village chickens in Tengeru ward, Arusha, Tanzania in June 2019. Out of 54 isolates, 46 were biochemically identified to be Salmonella Gallinarum (in the other study). The remaining eight isolates were non-S. Gallinarum subjected to molecular identification using PCR.

\section{DNA extraction}

The DNA extraction was done using the PowerSoil ${ }^{\circledR}$ DNA Isolation kit (MO BIO Laboratories, Inc.) according to the manufacturer's instruction. The quantity and purity of DNA were assessed using Nanodrop, and quality of DNA was checked on a gel of $1.5 \%(\mathrm{w} / \mathrm{v})$ agarose and visualized using ultraviolet (UV)-visible spectrophotometer (Cole-Parmer UV Transilluminator). The DNA was stored at $-20^{\circ} \mathrm{C}$ until use.

PCR

The PCR amplification was carried out with a $25 \mu \mathrm{L}$ amplification mixture consisting of $12.5 \mu \mathrm{L}$ master mix (OneTaq ${ }^{\circledR}$ Quick-Load $^{\circledR} 2 \times \mathrm{MM} \mathrm{w/Std.}$ buffer, BioLabs, New England), $0.5 \mu \mathrm{L}$ of $10 \mu \mathrm{M}$ each primer (Table-1), [24,25] $8.5 \mu \mathrm{L}$ of nuclease-free water, and $3.0 \mu \mathrm{L}$ DNA template. Amplification was conducted in a thermocycler $\left(\mathrm{C}-1000 \mathrm{Touch}^{\mathrm{TM}}\right.$ thermocycler). The cycle conditions consisted an initial denaturation $94^{\circ} \mathrm{C}$ for 1 min followed by 35 cycles of denaturation at $94^{\circ} \mathrm{C}$ for $60 \mathrm{~s}$, annealing at $64^{\circ} \mathrm{C}$ for $30 \mathrm{~s}$, and elongation at $72^{\circ} \mathrm{C}$ for $30 \mathrm{~s}$ with $7 \mathrm{~min}$ final extension period at $72^{\circ} \mathrm{C}$. The amplified products were separated by gel electrophoresis containing $1.5 \% \mathrm{w} / \mathrm{v}$ agarose (SRL, India) stained with ethidium bromide $(0.5 \mu \mathrm{g} / \mathrm{mL})$ and detected by gel documentation system (UVP, UK). The amplification cycles for $s p v C$ gene were similar to invA gene except the annealing temperature for $s p v C$ gene was $58^{\circ} \mathrm{C}$ instead of $64^{\circ} \mathrm{C}$ used for invA.

\section{Nucleotide sequencing of invA and spvC genes}

The positive PCR products were purified using the GeneJET Purification Kit (Thermo Fisher Scientific, MA, USA); then, the pure products were sequenced using both forward and reverse primers (Table-1).

A gene in an ABI $3730 \mathrm{XL}$ automated sequencer (Applied Biosystems, MA, USA) was in a custom sequencing facility of Mbeya Referral Hospital, Tanzania. The sequences obtained were analyzed, and homology searches were conducted using the BLAST algorithm (www.ncbi.nlm.nih.gov/BLAST).

\section{Results}

Four samples were amplified by invA gene. Three out of four of the same invA positive samples were also amplified by $s p v C$ gene (Table-1). The amplified samples were $100 \%$ similar with $S$. enterica serovar Typhimurium strain number 14028 with accession number CP034479.1 and S. enterica subspecies enterica serovar Typhimurium strain number 14028 with accession number CP034480.1

The positive PCR reactions in this study were observed by agarose jelly with $\sim 284$ and $\sim 571 \mathrm{bp}$ products for invA and $s p v C$ genes, respectively (Figure-1). The nucleotide sequence of the invA gene of $S$. Typhimurium strain obtained in this study was analyzed and $284 \mathrm{bp}$ sequences deposited with NCBI under GenBank accession number MK204827.

\section{Discussion}

In the present study, the detection of Salmonella spp. by conventional PCR was done using pair of primers (FS139-RS141) specific for the invA gene and FSPV-1 and RSPV-2 for the $s p v C$ gene. The selection of these genes was made based on those associated with virulence in Salmonella spp. [26]. The invA gene of Salmonella contains sequences unique to this genus and has been approved as a suitable PCR target with

Table 1: Primer pair used to amplify Salmonella isolates.

\begin{tabular}{|c|c|c|c|c|c|}
\hline Gene & Primers & Oligonucleotides $\left(5^{\prime}-3^{\prime}\right)$ & Annealing temperature & Length (bp) & Reference \\
\hline $\operatorname{invA}$ & $\begin{array}{l}\text { S139 } \\
\text { S141 }\end{array}$ & $\begin{array}{l}\text { GTG AAA TTA TCG CCA CGT TCG GGC AA } \\
\text { TCATCGCACCGTCAAAGGAACC }\end{array}$ & $64^{\circ} \mathrm{C}$ & 284 & [24] \\
\hline$s p v C$ & $\begin{array}{l}\text { SPV-1 } \\
\text { SPV-2 }\end{array}$ & $\begin{array}{l}\text { ACTCCTTGCACAACCAAATGCGGA } \\
\text { TGTCTTCTGCATTTCGCCACCATCA }\end{array}$ & $58^{\circ} \mathrm{C}$ & 571 & {$[25]$} \\
\hline
\end{tabular}

invA=Invasion $\mathrm{A}$ 


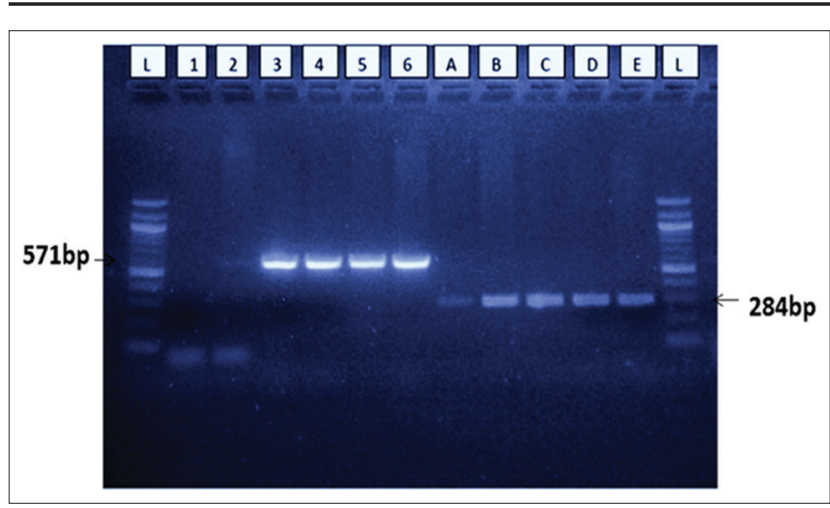

Figure-1: The polymerase chain reaction amplification for invA (284bp) and spvC (571bp) virulence gene of Salmonella spp. $L$ is the molecular weight marker (1000 bp), 1 is a negative control, 2, 3, 4, and 5 are samples, while 6 is positive control. The $B, C, D$, and $E$ are samples and $A$ is a positive control.

the potential diagnostic application [20]. This gene encodes a protein in the inner membrane of bacteria responsible for the invasion of the epithelial cells of the host [19]. On the other side, $s p v C$ gene targets invasive non-typhoidal Salmonella spp. that induces systemic infection to chickens $[27,28]$.

In this study, out of four samples amplified for invA gene, three were positive with $s p v C$. Following blasting of the sequences for inv $A$ positive, $s p v C$ positive, and $s p v C$ negative, it was revealed that all samples were $S$. enterica serovar Typhimurium. The lack of $s p v C$ gene to one sample of $S$. Typhimurium is an indication that the species is non-invasive compared to invasive non-typhoidal $S$. Typhimurium which possess $s p v C$ gene. In support of these findings, Guiney and Fierer [29] observed that three genes represent virulence phenotype in spv locus designated as $s p v R A B C D$ are positive transcriptional regulator $s p v R$ and two structural genes $s p v B$ and $s p v C$ [30]. The $s p v B C$ are sufficient to replace all of the spv genes, as well as the entire virulence plasmid to enable systemic infection in mice after subcutaneous inoculation [31]. However, in the absence of $s p v C, \operatorname{spv} B$ does not have a detectable virulence phenotype [21]. From these observations, it is suggested that $s p v C$ gene is the primary determinant of virulence in spv locus. However, the exact mechanisms by which $s p v B$ and $s p v C$ manage to enhance virulence are still unclear [31].

It is becoming clear that the virulence of $S$. Typhimurium identified from this study is attributed by the possession of both invA and $s p v C$ genes [32,33]. $S$. Typhimurium, which lacks $s p v C$ gene, eliminates the ability of plasmid to confer virulence to chickens $[21,34]$.

\section{Conclusion}

$\operatorname{Inv} A$ and $s p v C$ genes identified pathogenic and virulent strains of $S$. Typhimurium. The invA is a factor in the outer membrane of Salmonella spp., thus enables $S$. Typhimurium to initiate infection on the epithelial cell of chicken and induction of macrophage apoptosis. $S$. Typhimurium containing $s p v C$ gene is more virulent than those lacking this gene. This is because virulence plasmid with a structural gene $s p v C$ plays a role in the pathogenicity of $S$. Typhimurium. However, not all Salmonella serovars possess $s p v C$ gene responsible for virulence phenotype. Therefore, relying only on the $s p v C$ gene for the detection of Salmonella spp. may provide a high chance of false-positive results because some non-typhoidal Salmonella like $S$. Typhimurium possess $s p v C$ gene and others lack it.

\section{Authors' Contributions}

MM planned the study, collected samples, analyzed data, and developed the manuscript. ERM analyzed data, edited, and proofread the manuscript; MC analyzed data and wrote the manuscript. All authors read and approved the final manuscript.

\section{Acknowledgments}

The authors acknowledge the African Development Bank (AfDB) under grant number 21001550328, through the Nelson Mandela African Institution of Science and Technology, for funding this study. Also, the authors are thankful to the inhabitants of Tengeru ward for their genuine support during the collection of fecal samples from their chickens

\section{Competing Interests}

The authors declare that they have no competing interests.

\section{Publisher's Note}

Veterinary World remains neutral with regard to jurisdictional claims in published institutional affiliation.

\section{References}

1. Zeiner, S.A., Dwyer, B.E. and Clegg, S. (2012) FimA, FimF, and FimH are necessary for assembly of Type 1 fimbriae on Salmonella enterica serovar Typhimurium. Infect. Immun., 80(9): 3289-3296.

2. Carattoli, A. (2009) Resistance plasmid families in Enterobacteriaceae. Antimicrob. Agents Chemoth., 53(6): 2227-2238.

3. Eguale, T. (2018) Non-typhoidal Salmonella serovars in poultry farms in central Ethiopia: Prevalence and antimicrobial resistance. BMC Vet. Res., 14(1): 217.

4. Foley, S.L., Johnson, T.J., Ricke, S.C., Nayak, R. and Danzeisen, J. (2013) Salmonella pathogenicity and host adaptation in chicken-associated serovars. Microbiol. Mol. Biol. Rev., 77(4): 582-607.

5. Shehata, A.A., Basiouni, S., Elrazek, A.A., Sultan, H., Tarabees, R., Abd, M.S., Elsayed, E., Talat, S., Moharam, I., Said, A. and Mohsen, W.A. (2018) Characterization of Salmonella enterica isolated from poultry hatcheries and commercial broiler chickens. J. Infect. Dev Ctries., 11(4): 314-319.

6. Silva, C., Calva, E. and Maloy, S. (2014) One health and food-borne disease: Salmonella transmission between humans, animals, and plants. One Health, 2(5): 137-148.

7. Gopinath, S., Carden, S. and Monack, D. (2012) Shedding light on Salmonella carriers. Trends Microbiol., 20(7): 320-327.

8. Cox, N.A., Richardson, L.J., Maurer, J.J., Berrang, M.E., 
Fedorka-Cray, P.J., Buhr, R.J., Byrd, J.A., Lee, M.D., Hofacre, C.L., O'kane, P.M. and Lammerding, A.M. (2012) Evidence for horizontal and vertical transmission in Campylobacter passage from hen to her progeny. J. Food Prot., 75(10): 1896-1902.

9. Pande, V.V., Devon, R.L., Sharma, P., McWhorter, A.R. and Chousalkar, K.K. (2016) Study of Salmonella Typhimurium infection in laying hens. Front. Microbiol., 7: 203.

10. Paz-Méndez, A.M., Lamas, A., Vázquez, B., Miranda, J.M., Cepeda, A. and Franco, C.M. (2017) Effect of food residues in biofilm formation on stainless steel and polystyrene surfaces by Salmonella enterica strains isolated from poultry houses. Foods J., 6(12): 106.

11. Iñiguez-Moreno, M., Gutiérrez-Lomelí, M., GuerreroMedina, P.J. and Avila-Novoa, M.G. (2018) Biofilm formation by Staphylococcus aureus and Salmonella spp. Under mono and dual-species conditions and their sensitivity to cetrimonium bromide, peracetic acid and sodium hypochlorite. Braz. J. Microbiol., 49(2): 310-319.

12. Dar, M.A., Ahmad, S.M., Bhat, S.A., Ahmed, R., Urwat, U., Mumtaz, P.T., Dar, T.A., Shah, R.A. and Ganai, N.A. (2017) Salmonella Typhimurium in poultry: A review. Worlds Poult. Sci. J., 73(2): 345-354.

13. Guardabassi, L., Damborg, P., Stamm, I., Kopp, P.A., Broens, E.M., Toutain, P.L. and ESCMID Study Group for Veterinary Microbiology. (2017) Diagnostic microbiology in veterinary dermatology: Present and future. Vet. Dermatol., 28(1): 146-e30.

14. Váradi, L., Luo, J.L., Hibbs, D.E., Perry, J.D., Anderson, R.J., Orenga, S. and Groundwater, P.W. (2017) Methods for the detection and identification of pathogenic bacteria: Past, present, and future. Chem. Soc. Rev., 46(16): 4818-4832.

15. Sousa, A.M. and Pereira, M.O. (2013) A prospect of current microbial diagnosis methods. In: Microbial Pathogens and Strategies for Combating Them: Science, Technology and Education. Vol. 3. Formatex, Badajoz. p1429-1438.

16. Ahmed, O.B., Asghar, A.H., El-Rahim, I.H.A. and Hegazy, A.I. (2014) Detection of Salmonella in food samples by culture and polymerase chain reaction methods. $J$. Bacteriol. Parasitol., 5(3): 1.

17. Van Belkum, A., Durand, G., Peyret, M., Chatellier, S., Zambardi, G., Schrenzel, J., Shortridge, D., Engelhardt, A. and Dunne, W.M. (2013) Rapid clinical bacteriology and its future impact. Ann. Lab. Med., 33(1): 14-27.

18. Gawad, C., Koh, W. and Quake, S.R. (2016) Single-cell genome sequencing: Current state of the science. Nat. Rev. Genet., 17(3): 175-188.

19. Wang, Y.P., Li, L., Shen, J.Z., Yang, F.J. and Wu, Y.N (2009) Quinolone-resistance in Salmonella is associated with decreased mRNA expression of virulence genes invA and avrA, growth and intracellular invasion and survival. Vet. Microbiol., 133(4): 328-334.

20. Shanmugasamy, M., Velayutham, T. and Rajeswar, J. (2011) InvA gene specific PCR for detection of Salmonella from broilers. Vet. World, 4(12): 562.

21. Derakhshandeh, A., Firouzi, R. and Khoshbakht, R. (2013) Association of three plasmid-encoded spv genes among different Salmonella serotypes isolated from different origins. Indian J. Microbiol., 53(1): 106-110.

22. Mazurkiewicz, P., Thomas, J., Thompson, J.A., Liu, M., Arbibe, L., Sansonetti, P. and Holden, D.W. (2008) $S p v C$ is a Salmonella effector with phosphothreonine lyase activity on host mitogen activated protein kinases. Mol. Microbiol., 67(6): 1371-1383.

23. Mkrtchyan, M.S., Zakharyan, M.K., Arakelova, K.A., Sedrakyan, A.M., Gevorgyan, Z.U. and Ktsoyan, Z.A. (2016) Molecular determinants of virulence genes of Salmonella enteritidis prevailing in Armenia. Chem. Biol., 1(1): 55-60.

24. Kumar, K., Saklaini, A.C., Singh, S. and Singh, V.P. (2008) Evaluation of Specificity for invA Gene PCR for Detection of Salmonella spp. Proceeding of $7^{\text {th }}$ Annual Conference of Indian Association of Veterinary Public Health Specialists (IAVPHS).

25. Chiu, C.H. and. Ou, J.T. (1996) Rapid identification of Salmonella serovars in faeces by specific detection of virulence genes, invA and $s p v C$, by an enrichment broth culture-multiplex PCR combination assay. J. Clin. Microbiol., 34(10): 2619-2622.

26. Pal, S., Dey, S., Batabyal, K., Banerjee, A., Joardar, S.N., Samanta, I. and Isore, D.P. (2017) Characterization of Salmonella gallinarum isolates from backyard poultry by polymerase chain reaction detection of invasion $(\operatorname{invA})$ and Salmonella plasmid virulence $(s p v C)$ genes. Vet. World, 10(7): 814

27. Silva, C., Puente, J.L. and Calva, E. (2017) Salmonella virulence plasmid: Pathogenesis and ecology. Pathog. Dis., 75(6): 70

28. Haneda, T., Ishii, Y., Shimizu, H., Ohshima, K., Iida, N., Danbara, H. and Okada, N. (2012) Salmonella Type III effector $s p v C$, a phosphothreonine lyase, contributes to reduction in inflammatory response during intestinal phase of infection. Cell. Microbiol., 14(4): 485-499.

29. Guiney, D.G. and Fierer, J. (2011) The role of the spv genes in Salmonella pathogenesis. Front. Microbiol., 2: 129.

30. Guedda, I., Taminiau, B., Ferjani, A., Boukadida, J., Bertrand, S. and Daube, G. (2014) Antimicrobial and molecular analysis of Salmonella serovar Livingstone strains isolated from humans in Tunisia and Belgium. J. Infect. Dev. Ctries., 8(8): 973-980.

31. Matsui, H., Bacot, C.M., Garlington, W.A., Doyle, T.J., Roberts, S. and Gulig, P.A. (2001) Virulence plasmid-borne $s p v B$ and $s p v C$ genes can replace the 90-kilobase plasmid in conferring virulence to Salmonella enterica serovar Typhimurium in subcutaneously inoculated mice. $J$. Bacteriol., 183(15): 4652-4658.

32. Tasmin, R., Gulig, P.A. and Parveen, S. (2019) Detection of virulence plasmid-encoded genes in Salmonella Typhimurium and Salmonella Kentucky isolates recovered from commercially processed chicken carcasses. J. Food Prot., 82(8): 1364-1368

33. García, P., Hopkins, K.L., García, V., Beutlich, J., Mendoza, M.C., Threlfall, J., Mevius, D., Helmuth, R., Rodicio, M.R. and Guerra, B. (2014) Diversity of plasmids encoding virulence and resistance functions in Salmonella enterica subsp. Enterica serovar Typhimurium monophasic variant 4, [5], 12: I:-strains circulating in Europe. PloS One, 9(2): 89635 .

34. Matsui, H., Isshiki, Y., Eguchi, M., Ogawa, Y. and Shimoji, Y. (2014) Evaluation of the live vaccine efficacy of virulence plasmid-cured, and phoP-or aroA-deficient Salmonella enterica serovar Typhimurium in mice. J. Vet. Med. Sci., 77(2): 181-186. 